\title{
REVITALISASI PERLINDUNGAN ANAK DAN PEREMPUAN MENUJU PEMBANGUNAN BERKELANJUTAN (SUSTAINABLE DEVELOPMENT
}

GOALS)

\author{
Fransiska Novita Eleanora ${ }^{1}$, Lusia Sulastri ${ }^{2}$ \\ ${ }^{1}$ Fakultas Hukum, Ilmu Hukum, Universitas Bhayangkara Jakarta Raya, email: \\ fransiska.novita@dsn.ubharajaya.ac.id \\ ${ }^{2}$ Fakultas Hukum, Ilmu Hukum, Universitas Bhayangkara Jakarta Raya
}

\begin{abstract}
ABSTRAK
Penelitian ini bertujan untuk mengetahui revitalisasi dari perlindungan terhadap anak dan perempuan menuju pembangunan yang berkelanjutan atau disebut sebagai sustainable development golas. Perlindungan yang dimaksud disini adalah perlindungan akan pemenuhan terhadap hak-hak dari anak dan perempuan yang harus mendapat perhatian dikarenakan sangatlah rentan terhadap segala tindakan seperti diskriminasi juga kekerasan yang dapat mengakibatkan terjadinya pelanggaran terhadap hak akan hidupnya anak dan perempuan dimana pelanggaran tersebut merupakan suatu kejahatan atau tindak pidana. Perlindungan menuju pembangunan yang berkelanjutan memberikan perhatian dan fokus kepada kehidupan anak dan perempuan untuk mendapatkan pemenuhan dan perlindungan terhadap hak-haknya baik itu hak yang paling utama adalah menyangkut akan hak dalam mendapatkan adanya pendidikan dan juga pengajaran, mendapatkan kesehatan, juga mendapatkan tempat tinggal yang layak serta tidak diperakukan secara sewenang-wenang oleh siapapun juga dan berhak mendapatkan keadilan dan persamaan akan haknya. Rumusan Masalah yaitu bagaimana revitaliasi terhadap perlindungan manak dan perempuan menuju pembangunan yang berkelanjutan. Metode penelitian yang digunakan adalah penelitian yang yuridis normatif adalah suatu pendekatan yang berdasarkan bahan hukum yang utama berdasarkan konsep yang ada, teori, asa-asas hukum serta peraturan perundangan yang berkaitan dengan penelitian ini. Hasilnya adalah pembangunan yang berkelanjutan dapat terealisasi jika ada kerjasama dan koordinasi antara berbagai pihak termasuk masyarakat untuk selalu memperhatikan dan peduli terhadap perlindungan anak dan perempuan.
\end{abstract}

ARTICLE INFO

Kata Kunci: perlindungam, anak; perempuan; pembangunan; berkelanjutan

Cite this paper:

Fransiska Novita Eleanora, L. S., 2020. Revitalisasi Perlindungan Anak Dan Perempuan Menuju Pembangunan Berkelanjutan (Sustainable Development Goals). Widya Yuridika: Jurnal Hukum, 3(2).

\section{PENDAHULUAN}

Sebagai Negara yang merdeka dan berdaulat, Indonesia memegang prinsip-prinsip dari rule of the law, dimana salah satunya adalah terlindunginya hak-hak asasi dari manusia dan direalisakan dengan berbagai peraturan tentang perlindungan terhadap 
anak dan perempuan, bahkan adanya Konvensi Hak Anak (KHA), atau lebih dikenal dengan UN-CRC (United Nations Convention on the Rights of the Child) adalah sesuatu atau sebuah bentuk dari perjanjian dari adanya hak asasi manusia dan menjamin hak anak dalam bidang pada bidang sipil, bidang politik, juga ekonomi, dan sosial, serta kesehatan, dan juga budaya yang sudah disahkan pada tahun 1989 oleh Perserikatan Bangsa-Bangsa atau disingkat juga dengan PBB. Indonesia telah meratifikasi KHA ini pada Tahun 1990, yaitu 12 tahun setelahnya, dan mengadopsi konvensi ini ke dalam UndangUndnag Nomor 23 Tahun 2002 tentang Perlindungan Anak yang juga kemudian direvisi pada tahun 2014 yaitu Undang-Undang Nomor 35 Tahun 20141.

Tujuan dari adanya Undang-Undang mengenai perlindungan anak untuk menjamin dan juga melindungi akan adanya hak-hak dari seorang anak untuk selalu dapat hidup, dan tumbuh juga berkembang dan juga dapat untuk berpartisipasi dan juga secara optimal yang sesuai dengan adanya harkat dan juga martabat dari kemanusiaan serta juga mendapatkan suatu adanya perlindungan dari segala tindakan kekerasan dan juga diskriminasi, dengan kata lain segala tindakan apapun yang dapat merusak akan perkembangan dari anak tidak diperkenankan apalagi sampai melanggar akan hak-hak anak, karena anak berhak dilindungi dari segala bentuk ancaman atau tindakan yang dapat membahayakan dirinya, dan yang dapat melindungi anak adalah orang dewasa dengan segala perbuatan yang melindunginya.

Begitupula dengan perlindungan terhadap perempuan CEDAW (The Convention of The Elimination of All Forms Women) adalah merupakan kesepakatan yang International untuk penghapusan terhadap adanya diskriminasi yang terjadi terhadap atau pada perempuan, dimana konvensi ini mendefinisikan prinsip-prinsip dari hak asasi terhadap perempuan sebagai hak asasi manusia dimana berisi mengenai norma-norma, dan standar-standar kewajiban, dan juga tanggungjawab negara dalam penghapusan diskriminasi terhadap perempuan, dan Indonesia adalah merupakan satu dari beberapa Negara yang turut serta dan ikut juga dalam menandatangani terhadap konvensi ini pada 24 Juli 1984 dan telah meratifikasinya dengan Undang-Undang Republik Indonesia dengan Nomor 7 Tahun $1984^{2}$

Perlindungan terhadap anak dan perempuan menjadi tanggungjawab dari semua pihak tanpa terkecuali, dimana perlindungan yang diberikan adalah perlindungan akan hak-haknya yang secara khusus akan hak-hak hidupnya seperti mendapatkan adanya pendidikan dan juga dengan pengajaran, juga karena anak mempunyai hak yang sama dengan orang dewasa pada umumnya dan tidak ada perbedaan sedikitpun juga serta menghindari segala tindakan-tindakan yang dapat merusak dan mengganggu kejiwaan anak seperti menghindari dan mencegah akan segala tindakan-tindakan yang menyangkut kekerasan baik secara fisik, juga psikis, seksual dan juga tindakan tindakan penelantaran anak atau juga tindakan diskriminasi yang dapat memberikan keadaan yang tidak bagi pertumbuhan bagi anak ${ }^{3}$

Sejalan dengan hal tersebut diatas tidak terlepas juga dari perlindungan terhadap perempuan, dan perlindungan juga diutamakan akan hak-haknya, yang mencakup untuk mendapatkan pendidikan dan pengajaran harus adanya kesetaraan gender antara lakilaki dan perlindungan, dimana perempuan berhak untuk memperoleh pendidikan yang

\footnotetext{
${ }^{1}$ https://puskapa.org/seri-belajar/722/diakses, 2 September 2020, Jam, 11.20 wib

https://www.komnasperempuan.go.id/read-news-siaran-pers-komnas-perempuan-catatan-komnas-perempuan-33-tahunratifikasi-konvensi-cedaw-di-indonesia, diakses 4 September 2020, Jam, 09.00 wib

${ }^{3}$ Simbolon Laurensius Arliman, 2016, Partisipasi Masyarakat di Dalam Perlindungan Anak Yang Berkelanjutan Sebagai Bentuk Kesadaran Hukum, Padjajaran Journal of Law, Vol. 3 (2), hal. 315
} 
sama tanpa adanya perbedaan begitupula perlindungan dalam bidang ketenagakerjaan, mendapatkan upah yang sama, juga kesehatan akan reproduksinya, serta dalam bidang perkawinan dan harta bersama ataupun dalam pengurusan anak, perlindungan akan perbuatan dalam hukum berhak mendapatkan keadilan dan perlakuan yang sama, berhak mendapatkan tempat tinggal yang layak serta lingkungan yang sehat.

Revitalisasi atau proses perlindungan anak dan perempuan perlu mendapatkan perhatian yang khusus dari semua pihak dalam melindungi anak dan perempuan, dan perlindungan tersebut merupakan tujuan dari jangka yang panjang adalah untuk dapat mewujudkan masyarakat adil dan makmur, dan juga mewujudkan pembangunan yang berkelanjutan yang berkeadilan dan mandiri dan mendorong perlakuan yang adil antara laki-laki dan perempuan ${ }^{4}$ sama derajat dan haknya, untuk selalu dilindungi secara khusus.

Perlindungan yang dapat menuju suatu arah dari pembangunan yang berkelanjutan dapat dimulai dari lingkungan keluarga terkecil yaitu dari orangtua dimana orantua bertanggungjawab dalam menjalankan perannya dalam membimbing dan mendidik anak-anaknya, dan menghindari sikap yang tidak baik, menyediakan dan memberikan waktu luang bagi anak, dan dapat menjadi sahabat anak dalam mencurahkan isi hatinya, begitupula dengan perempuan untuk selalu mendapat perlindungan juga dimulai dari keluarga, dan jika sudah menikah mencakup juga aspek dalam rumah tangganya yaitu menghindari dan mencegah terjadinya suatu tindakan atau perbuatan akan kekerasan yang terjadi di dalam sebuah rumah tangga dan dapat berujung pada penganiayaan, luka yang berat bahkan bisa terjadi kematian. Dan jika hal tersebut sampai terjadi maka sudah dapat disebut sebagai tindak pidana, artinya pelakunya dapat dituntut dimuka hukum dengan terpenuhinya unsur-unsur tindakan dari perbuatan yang dapat dihukum, dikarenakan sudah termasuk dalam ranah pelanggaran terhadap manusia dan juga akan hak asasinya itu sendiri, karena sudah adanya penyiksaan serta perlakuan yang menyebabkan terjadinya kekerasan pada anak dan perempuan itu sendiri ${ }^{5}$.

Perlindungan terhadap hak asasi manusia terkhusus anak dan perempuan merupakan tugas dan tanggungjawab semua pihak, termasuk juga pemerintah dalam memberikan perlindungan sebagai warganegara, dan perlindungan ini merupakan tujuan dari pembangunan, yaitu yang sesuai dengan tujuan pembangunan nasional dalam pembukaan dari Undang-Undang Dasar 1945 bahwa ada 4 (empat) pokok dari tujuan nasional yaitu melindungi akan segenap bangsa Indonesia dan juga seluruh akan tumpah darah Indonesia, memajukan akan kesejahteraan umum, juga mencerdaskan kehidupan dari bangsa, dan ikut dalam melaksanakan akan ketertiban dunia yang berdasarkan akan kemerdekaan, serta perdamaian yang abadi, dan juga keadilan sosial, itulah tujuan untuk memajukan serta berkaitan dengan perlindungan dan pengakuan terhadap hak-hak asasi dari manusia 6

Tujuan dari pembangunan nasional ini setidaknya tidak sampai disini saja, tapi harus dilanjutkan mengingat pembangunan perlu adanya dilakukan pendekatan pendekatan dari sisi kemanusiaan yang tak lain sisi dari hak asasi manusia, dimana pembangunan harus selalu mengutamakan kebebasan dari hak masing-masing individu, tidak adanya lagi penyiksaan, perlakuan yang tidak menyenangkan, dan lebih mengutamakan perlindungan dan pemenuhan hak terhadap generasi penerus, dari bangsa, adanya kesetaraan keadilan disetiap aspek bidang kehidupan, dikarenakan

\footnotetext{
4 Barakati, Morais, 2015, Perspektof Konsep Hak Asasi Manusia Dalam Mewujudkan Pembangunan Lingkungan Hidup Yang Berkelanjutan, Lex Et Societatis, Vol. 3 (8), hal. 91

${ }^{5}$ Ibid, hal. 89

${ }^{6}$ Ibid, hal. 93
} 
pembangunan harus dapat membangun akan adanya karakter yang lebih baik lagi dari bangas ${ }^{7}$. Dalam perkembangan yang mutakhir, pengaitan antara Hak Asasi Manusia (HAM) dengan pembangunan akan menjadi suatu isu yang selalu berkembang akhir dekade dari 1980-an dan juga awal tahun 1990an. Dimana persoalan-persoalan dalam pembangunan yang memang selalu berkaitan dengan adanya penegakkan HAM dan sangat dirasakan akan menjadi semakin lebih serius dan juga mendesak, dan tidak hanya pada negara-negara yang sudah berkembang, tetapi juga dan melainkan di negara-negara yang industrinya sudah maju

Tantangan yang dihadapi dan sangat mengganggu adalah cara pandang sebagian kalangan yang beranggapan atau menganggap bahwa HAM merupakan konsep yang menghalangi proses akan pembangunan ${ }^{8}$. Pihak-pihak yang selalu mengedepankan HAM dianggap mengabaikan terhadap kepentingan umum dan juga kepentingan nasional yang lebih besar. Dalam pembangunan ini, pengingkaran terhadap hak-hak individu juga dimungkinkan menurut dari cara pandang ini. Pembangunan harus selalu juga dikawal dengan adanya stabilitas dari politik yang juga secara konkret dapat bermakna akan pembatasan dari hak-hak individu9 ${ }^{9}$. Cara pandang yang dapat mempertentangkan tersebut dapat berakibat pada terjadinya berbagai adanya suatu pelanggaran dari HAM yang memang disebabkan oleh adanya praktek-praktek yang represif, pembatasan dari partisipasi rakyat, dan juga eksploitasi, baik dari segi akan alam dan sumbernya maupun dari sumber daya manusia itu sendiri ${ }^{10}$.

Pembangunan nasional akan terus berlanjut menuju pembangunan yang berkelanjutan (sustainable develpoment goals), dimana proses menuju pembangunan ini adalah salah satunya mendapat dukungan dari masyarakat termasuk juga pemahaman akan sumberdaya manusia, dan juga pihak-pihak permerhati akan perlindungan anak dan perempuan, merasa terpanggil untuk memberikan perlindungan bagi anak dan perempuan, termasuk juga denga peran serta dari negara melalui aparatnya dalam membuat atau melaksanakan peraturan perundang-undangan dan pelaksana di lapangan, dengan kata lain bahwa dalam menuju pembangunan yang berkelanjutan ini semua pihak sudah memahami akan tugas dan fungsi dan tanggungjawab yang ada ${ }^{11}$. Berdasarkan pendahuluan diatas, maka masalah yang perlu dikaji adalah bagaimana revitalisasi perlindungan anak dan perempuan menuju pembangunan yang berkelanjutan (sustainable development goals) dimana penelitian ini memberikan suatu gambaran mengenai tujuan dan prinsip dalam menuju pembangunan yang berkelanjutan sesuai dengan penegakan hak hak asasi manusia.

Dalam penelitian digunakan metode penelitian yang yuridis dan juga normatif adalah berdasarkan dari suatu pendekatan dari bahan hukum yang utama atau penting dengan cara dan juga menelaah akan konsep-konsep dan teori-teori hukum serta asasasas hukum dan teori terhadap perundang-undangan yang ada dan memang berhubungan dengan adanya penelitian ini. Metode penelitian yang yuridis normatif, juga dikenal dengan pendekatan yang kepustakaan yakni dengan mempelajari juga buku-buku yang ada dan juga peraturan perundang-undangan serta atau dan dokumen lain yang ada

\footnotetext{
${ }^{7}$ Dewi, Yusriani Sapta, 2011, Peran Perempuan Dalam Pembagunan Berkelanjutan Women In Sustainable Development, Jurnal Pendidikan Lingkungan dan Pembangunan Berkelanjutan, Vol. 12 (2), hal. 62

8 Probosiwi, Ratih, 2015, Perempuan dan Perannya dalam Pembangunan Kesejahteraan Sosial, NATAPRAJA Jurnal Kajian Ilmu Administrasi Negara, Vol. 3 (1), hal. 43

${ }^{9}$ Ibid, hal. 46

${ }^{10}$ Dardiri Hasyim, 2008, Perencanaan Pembangunan Berwawasan HAM Menuju Pembangunan Berpusat Pada HAM, UNISIA, Jurnal IlmuIlmu Sosial, Vol. 31 (68), hal. 5
} 
hubungannya atau terkait dengan penelitian ini. Sifatnya adalah deskriptif, artinya penelitian tersebut dapat menggambarkan suatu objek yang tertentu dan juga menjelaskan akan hal-hal yang terkait dengan atau dapat melukiskan secara sistematis akan suatu fakta-fakta atau keadaan secara factual dan cermat ${ }^{12}$. Jenis penelitian adalah pendekatan yang kualitatif dimana penelitiannya yang bertujuan untuk mencari tentang sebab dan akibat sesuatu terjadi, tetapi berupaya untuk dapat memahami akan situasi yang tertentu dan juga berupaya untuk mendalami dan juga menerobos gejala serta menginterprestasikan suatu masalah yang dapat disajikan oleh keadaan situasinya ${ }^{13}$

\section{HASIL DAN PEMBAHASAN Anak dan Perempuan}

Banyak istilah yang memberikan pengertian atau definisi tentang anak, bahkan berbagai peraturan perundangan juga memberikan definisi tersebut, dalam wikipedia indonesia disebutkan bahwa anak anak adalah seorang laki-laki atau perempuan yang belum menginjak dewasa atau belum juga mengalami masa yang pubertas ${ }^{14}$. Sedangkan pengertian anak dari berbagai peraturan perundang-undangan yang ada, yaitu meliputi ;

a. Undang-Undang Nomor 35 tahun 2014 tentang perubahan Undnag-Undang Nomor 23 tahun 2002 Tentang Perlindungan Anak adalah seseorang atau yang memang belum berusia atau berumur 18 (delapan belas tahun), termasuk dalam pengertian ini anak yang berada dalam kandungan

b. Kitab Undang-Undang Hukum Perdata, sesuai dengan ketentuan dari pasal 330 KUHPERDATA, disebutkan bahwa mereka yang memang belum disebut dewasa adalah yang belum mencapai 21 tahun dan belum kawin, namun sebelum mencapai 21 tahun sudah menikah tetapi bercerai mati atau hidup tetap dianggap sebegai dewasa karena sudah pernah menikah ${ }^{15}$.

c. Undang-Undang Nomor 4 Tahun 1979 Tentang Kesejahteraan Anak, yang disebut dengan anak adalah seseorang yang belum atau dimana mencapai umur 21 (dua puluh satu ) tahun dan belum pernah kawin

d. Undang-Undang Nomor 11 Tahun 2012 Tentang Sistem Peradilan Pidana Anak yaitu anak yang telah atau sudah berumur 12 (dua belas) tahun, tetapi belum berusia atau berumur 18 (delapan belas) tahun yang diduga telah melakukan perbuatan tindak pidana

e. Undang-Undang Nomor 39 Tahun 1999 Tentang Hak Asasi Manusia

Anak adalah setiap manusia yang berusia atau di bawah 18 (delapan belas) tahun dan belum menikah, termasuk dalam defiini ini anak yang masih berada di dalam kandungan apabila hal tersebut demi kepentingannya

Batasan dari anak sangat penting termasuk dalam perkara pidana anak, karena untuk dapat mengetahui apakah bahwa seseorang yang melakukan kejahatan itu tergolong anak atau bukan, karena jika seorang anak melakukan perbuatan pidana tentunya hukumannya sangat berbeda dengan hukuman orang dewasa, begitupula dengan lembaga pemasyarakatannya, dikarenakan anak dan orang dewasa tidak boleh digabung atau dijadikan satu dalam satu sel.

Setelah membahas anak dan batasan usia kedewasaannya maka akan dikaji mengenai pengertian dengan arti dari kata atau makna perempuan itu sendiri, dimana

\footnotetext{
${ }^{12}$ Rihardi, Satrio Ageng, 2018, Perlundungan Hukum Terhadap Hak-Hak Anak Perempuan Sebagai Korban Eksploitasi Seksual, Jurnal Literasi Hukum Vol. 2 (1), hal. 63

13 Ibid, hal. 68

${ }^{14}$ Ibid. hal. 70

15 R. Subekti dan R. Tjitrosudibio, 2001, Kitab Undang-Undang Hukum Perdata, PT.Pradnya Paramita, Jakarta, hal. 90
} 
secara etimologis kata perempuan yang memang berasal dari suatu kata "empu" yang memang disebut atau berarti tuan yaitu orang yang mahir atau berkuasa, atau bisa juga kepala, diartikan sebagai suatu hulu, atau memang disebut suatu paling dan besar. Namun Zaitunah Subhan mengartikan bahwa kata atau makna dari perempuan dari suatu kata yang disebut empu dimana artinya dihargai, dan adanya suatu pergeseran akan istilah dari wanita kepada perempuan. Sehingga dari suatu bahasa yang sansekerta muncullah kata akan wanita, dengan adanya dasar akan kata wan yang menang berarti adanya nafsu, sehingga kata akan wanita dapat diartikan sebagai dinafsui atau juga merupakan suatu objek dari seks ${ }^{16}$.

Gambaran akan adanya perempuan menurut adanya suatu pandangan yang didasarkan pada medis dan kajiannya, adanya psikologis dan juga sosial, akan terbagi dalam 2 (dua) faktor yaitu adanya faktor yang fisik dan juga psikis, secara biologis dan juga fisik, dari perempuan dan dibedakan juga atas dasar fisik dari perempuan yang memang kecil jika dibandingkan dengan laki-laki, suara lebih halus, juga lemah lembut dan juga perkembangan akan tubuh dari perempuan terjadi sangat dini dan kekuatan dari perempuan tidaklah sekuat tubuh dari laki-laki. Dan jika diamati dari segi psikis perkembangan perempuan mempunyai sikap dan pelakuan yang kalem, adanya kecenderungan perasaan perempuan yang lebih cenderung cepat dan mudah menangis dan juga terkadang bisa pingsan apabila menghadapi suatu persoalan yang berat ${ }^{17}$

\section{Penegakan Hak Asasi Manusia}

Penegakan hukum dimana dalam suatu Bahasa Inggris disebut dengan law enforcement yaitu pengawasan yang dilakukan oleh Pemerintah untuk ditaatinya peraturan tersebut sejajar dengan pennyidikan dalam hukum pidana, dan disertai dengan penerapannya ( atau dengan amcaman) dengan adanya penggunaan instrumen administratif, dan kepidanaan juga keperdataan dicapailah akan penataan terhadap hukum terhadap peraturan yang berlaku umun dan juga yang individual ${ }^{18}$

Penegakan hukum bukanlah suatu yang merupakan proses yang logis melainkan sarat dengan suatu keterlibatan manusia yang didalamnya, artinya penegakan hukum sarat dengan dimensi dalam perilaku manusia, adanya keterlibatan dari masyarakat dan anggota dalam suatu menegakkan suatu hukum dapat terjadi baik di bidang hukum publik maupun pidana. Maka anggota dari masyarakat tersebut dapat juga melaporkan jika terjadi suatu penyimpangan atau kejahatan, dan dapat menggerakkan roda dari hukum pidana. Apabila anggota masyarakat itu tidak melakukan tindakan maka dianggap tidak ada kasus, sebaliknya dalam bidang publik atau perdata dimana peranan dari anggota masyarakat jauh lebih besar, oleh karena munculnya kasus hukum sepenuhnya dan diserahkan kepada masyarakat ${ }^{19}$

Dengan kata lain penegakan hukum merupakan suatu proses dalam melaksanakan dan mewujudkan suatu tujuan-tujuan mejadi suatu kenyataan, dimana dalam prosesnya harus melibatkan, pembuat, juga pelaksana dan masyaraakatnya, dan hukum jika diterima sebagai konsep yang modern dapat memiliki kemampuan dalam menyalurkan dalam hasil atas keputusan suatu politik. Sehingga dalam kaitannya penegakan hukum dan pembangunan harus saling terkait dalam membangun manusia Indonesia yang seutuhnya dan juga memahami akan adanya pembangunan hukum yang berorientasi pada rule of law, yang haus mendasarkan kepada perlindungan dan penegakan akan hak

\footnotetext{
16 Zaitunah, Subhan. 2004. Kekerasan Terhadap Perempuan. Pustaka Pesantren: Yogyakarta, hal. 19

${ }^{17}$ Murtadha Muthahhari. 1995. Falsafah Akhlak, Pustaka Hidayah, Bandung, hal. 110

${ }_{18}$ Rizky Ariestandi Irmasyah, 2013, Hukum, Hak Asasi Manusia dan Demokrasi, Graha Ilmu, Yogyakarta, hal. 83

${ }^{19}$ Ibid, hal. 84
} 
asasi setiap warga negara terkhusus bagi yang sangat rentan dan lemah perlunya diberikan perlindungan secara memadai akan hak-haknya itu.

Sehingga dapat juga diasumsikan bahwa penegakan hukum itu dibatasi oleh faktor yang sosial dan juga personal seperti pendidikan dna juga pendapatan (sebagai faktor yang sosial) serta sikap (sebagai faktor yang juga personal). Menurut Soerjono Soekanto ada beberapa hal atau faktor yang dapat atau bisa mempenagruhi dari penegakan hukum yang ada di Indonesia, antara lain:

a. Faktor undang-undang, disebabkan karena tidak diikutinya suatu atau asasasas berlakunya dari undang-undang yang ada, dan belum adanya peraturan dan pelaksanaan yang memang sangat dibutuhkan dalam menerapkan aturan tersebut. atau ketidakjelasan dalam arti kata dalam undang-undnag yang biasanya menimbulkan suatu adanya multitafsir

b. Faktor dari Penegak Hukum yaitu adanya pihak yang membentuk dan juga menerapkan hukum, dimana biasanya penegak hukum mengalami suatu keterbatasan dalam menempatkan diri, dan juga aspiratif yang kurang, dalam membuat proyeksi sangat berkurang dan inovatif juga berkurang

c. Faktor sarana dan juga adanya adanya fasilitas, yang memang mendukung adanya suatu penegakan hukum dimana tanpa adanya sarana dan juga adanya fasilitas, sehingga tidaklah mungkin suatu penegakan hukum akan dapat berlangsung dengan baik dan juga lancar. Dimana sarana dan fasilitas ini mencakup dari sumber daya yang berpotensi serta trampil dan juga berpendidikan serta adanya peralatan dan juga faktor ekonomi yang memang memadai

d. Faktor dari Masyarakat, yaitu berkaitan diaman hukum itu diterapakan dan berlaku. Biasanya banyak dari masyarakat seringkali tidak mengaetahui dan menyadari akan hak-haknya mereka terutama jika hak-haknya itu dilanggar, dan akibat ketidaktahuan tersebut berimbas pada bagaimana upaya hukum yang akan ditempuh, dan prosedurnya ditempuh, adanya kurangnya suatu pengetahuan politik dan juga sosial kurangnya pengatahuan dan pemahaman tentang finasial dan juga maslaah yang berkaitan dengan psikis, perlu ditanamlan dan ditumbuhkan rasa pemahaman dan pengetahuan yang mendalam dalam masyarakat sehingga masyarakat paham bagaimana jika hakhaknya dilanggar kemana harus melakukan laporan dan pengaduan, sehingga perlu dilakukan sosialisasi atau penyuluhan terhadap masyarakat.

e. Faktor dari kebudayaan, dimana hukum yang digunakan dan dipakai di Indonesia tidak saja berasal atau tumbuh dari masyarakat itu sendiri, melainkan datang dari luar negeri bersamaan atau berdasarkan dengan asas yang disebut dengan konkordansi, adanya asas yang dapat melandasi dengan diberlakukannya dari negara eropa akan hukumnya dan di Belanda pada saat itu atau waktu itu diberlakukan juga kepada golongan dari eropa yang saat itu ada di Hindia Belanda, dan pada saat Belanda datang ke Indonesia ditemukannya suatu hukum yang terdapat dalam kehidupan dari masyarakat, berupa kebisaan dan juga adat istiadat bahkan dengan tatanan dari hukum islam, dimana dapat dsebutkan tidak membangun hukum yang modern melainkan menerima dari luar ${ }^{20}$.

\section{Kesetaraan Gender}

${ }^{20}$ Ibid, hal. 85 
Gender diberikan dengan pemaknaan jenis kelamin yaitu menunjukkan adanya perbedaan perempuan dan juga laki-laki, dimana setiap perbedaan itu memilik sifat-sifat seperti laki-laki dianggap kuat, keras, dan memiliki karekter yang teguh pendirian dan menyelesaikan masalah tidak menangis sebaliknya perempuan cenderung memiliki lemahlembut, dan kasih sayang, juga keibuan dan jika memiliki masalah sering menyelesaikannya dengan berlinangan air mata atau mudah menangis. Sehingga lebih tepatnya kajian mengenai isu dari gender lebih mengarah pada makna kesetaraan dan menunjukkan pembagian terhadap tugas yang seimbang dan adil dari perempuan dan juga laki-laki, adanya kesetaraan akan laki-laki dan juga perempuan, dan mneyadari sepenuhnya akan tugas dan tanggungjawabnya.

Untuk lebih dapat dalam memberikan pemahaman akan arti atau makna dari kesetaraan antara laki-laki dan perempuan, yang dimana dalam hal ini seringkali juga disebut dengan istilah atau definsi dari kesetaraan gender, dimana pembagian tugas dan tanggungjawab misalnya hal-hal berikut :

a. Perempuan melaksanakan atau melakukan segala seuatu pekerjaan dalam rumah tangganya, sedangkan dari laki-laki dianggap tidak bisa atau tidak pantas dalam melakukan pekerjaan rumah tangga

b. Tugas yang utama dari laki-laki yaitu mengelola kebun, sedangkan tugas dari perempuan hanyalah membantu saja

c. Laki-laki lebih pantas untuk menjadi pemimpin dalam suatu masyarakat (yaitu lembaga dari adat, juga memimpin desa sebagai kepala, dsb)

d. Kegiatan yang berkaitan dengan pembinaan kesejahteraan dalam keluarga dan juga program kesehatan keluarga, perempuan leih pantas melakukannya ${ }^{21}$

Adanya ketidaksetaraan gender menjadi angka yang tinggi di Indonesia, padahal setiap orang berhak dengan haknya masing-masing dan tidak diperbolehkan adanya diskriminasiataupun perbedaan dalam cara apapun antara anak laki-laki dengan anak perempuan atau orang dewasa perempuan dan laki-laki semua sama dan berhak mendapatkan hak-haknya adanya sama mendapat perlakuan di mata hukum. ketidaksetaraan tersebut dapat mengakibatkan salah satu pihak menjadi lemah dan tidak berdaya dikarenakan tidak diberikan kesempatan untuk mendapatkan haknya alam setiap aspek segala bidang yang ada, dan ini sering terjadi bagi kaum yang sangat lemah dan rentan dengan kekerasan, yaitu anak dan perempuan, anak sebagai pihak yang lemah tentunya berhak untuk mendapatkan perlindungan dari orang dewasa tetapi sering disalahgunakan dan terkadang dijadikan aset sehingga terkadang terjadilah pernikahan dini, sedangkan perempuan sering terjadi tindak pidana akan kekerasan dalam suatu atau lingkup dari rumah tangga yang selalu berujung perceraian ${ }^{22}$.

Tingginya angka terhadap ketidaksetaraan gender ini sering terjadi dalam berbagai kasus seperti adanya perkawinan anak atau biasa disebut dengan pernikahan usia dini, dimana masih terdapat anak-anak yang seharusnya mendapatkan pendidikan dan bersekolah, menjalanu masa kanak-kanaknya agar kelak dapat meraih cita-citanya dan masa depannya tetapi diharuskan untuk menikah diusia yang sangat muda dan sangat belia dimana tentunya sering terjadi ketidaksiapan dalam mental juga jiwa dan psikologisnya dari anak tersebut. Akibat dari ketidaksiapannya tersebut dapat mengakibatkan terjadinya rumah tangga dalam tindakan kekerasan dan berujung pada

\footnotetext{
${ }^{21}$ Nan Rahminawati, Isu Kesetaraan Laki-Laki dan Perempuan (Bias Gender) , MIMBAR Jurnal Sosial dan Pembangunan, Vol. 17 (3) Tahun 2001, hal. 273

22 Rumtianing Irma, 2014, Kota Layak Anak Dalam Perspektif Perlindungan Anak, Jurnal Pendidikan Pancasila dan Kewarganegaraan, Vol 27 (1), hal. 8
} 
perceraian atau perpisahan diantara pasangannya, ketidaksiapan tersebut dapat mengakibatkan rusaknya kesehatan anak perempuan dan terkadang bayi yang dilahirkan mengalami prematur atau keguguran, disebabkan karena ketidaksiapan itu, memang ada juga faktor yang dapat menyebabkan terjadinya perkawinan anak seperti ekonomi, kemiskinan dan juga terkadang pergaulan yang bebas atau orang tua yang takut anaknya berzina sehingga disuruh untuk kawin, dan semuanya itulah yang mengakibatkan ketidaksiapan dalam menuju pelaminan atau perkawinan ${ }^{23}$.

Kesetaraan harus mulai dibangun dari keluarga sebagai penopang hidup dan landasan bagi anak-anak, lalu persepsi masyarakat juga turut dibangun, banyaknya atau seringnya terjadi anggapan bahwa anak-anak perempuan harus cepat-cepat untuk dinikahkan di usia muda, dan bukan itu saja ada beberapa faktor yang menyebabkan terjadonya pernikahan dini atau perkawainan anak yang paling menonjol adalah faktor dari segi ekonomi, dengan dampak ekonomi dan kesulitan dalam mencari nafkah sehingga anaknya dipaksa untuk menikah atau karena jeratan hutang persepsi demikian yag harus dihilangkan dan juga atau timbilnya suatu pandangan bahwa anak perempuan tidak boleh untuk bersekolah setinggi-tingginya karena pasti akan melayani keluarga yaitu suami dan anak, dan anak perempuan terkadang dianggap tidak memiliki kontrol terhadap dirinya sendiri.

Kesetaraan di dalam gender perlu dibangun dengan meningkatkan 4 (empat) hal yaitu akses, dan partisipasi juga kontrol dan juga mendapatkan manfaat untuk dapat meningkatakan adanya kualitas hidup dan mengakomodir mengenai pentingnya kesetaraan gender, sehingga di perlukan adanya pengarusutamaan terhadap gender dan secara terpadu dan juga terkoordinasi dan juga bertujuan untuk dapat meningkatkan akan adanya kualitas dari manusianya dan juga mewujudkan akan kesejahteraan rakyat, Sumber Daya Manusia yang harus selalu ditingkatkan karena merupakan kunci dari keberhasilan terhadap pembangunan yang disesuaikan dengan adanya keberagaman dan aspirasi dan juga hambatan akan kemajuan dari suatu kelompok terhadap masyarakat, dan hal merupakan tujuan dari pembagunan nasional ${ }^{24}$

\section{DISKUSI}

Menyelenggarakan suatu pembangunan nasional diperlukan suatu perencanaan, dan perencanaan tersebut dilakukan agar pembangunan tersebut terarah, dan cara dalam mencapai pembangunan nasional yang berkelanjutan itu agar dapat mensejahterahkan masyarakatnya dengan konsepsi terhadap atau dalam pembangunan yang nasional dan juga berkelanjutan yang mana dalam hal ini bertujuan bukan hanya untuk atau dapat memberikan kesejahteraan di masa kini, namun juga di masa lalu, kini, dan juga masa mendatang. Konsepsi akan pembangunan yang berkelanjutan ini hanya bisa dan dapat dijamin oleh hukum dan hukum ini yang menjaminnya pun harus selalu tetap melakukan pembangunan untuk dapat bersama-sama dengan pembangunan nasional menyejahterakan rakyatnya.

Terdapat 2 (dua) aspek penekanan utama dalam SDGs ini, yaitu pertama, menyangkut akan pentingnya dalam memperhatikan kendala atau hambatan yang terdapat di alam dan sumbernya serta lingkungan terhadap adanya pola akan pembangunan dan juga akan konsumsi. kedua, menyangkut akan perhatian yang serius

\footnotetext{
${ }^{23}$ https://www.voaindonesia.com/a/ketidaksetaraan-gender-masih-tinggi-di-indonesia-/5316082.html, diakses 7 September 2020, Jam, 19.30 wib

24 https://www.kemenpppa.go.id/index.php/page/read/31/1667/kesetaraan-gender-perlu-sinergi-antar-kementerian-lembagapemerintah-daerah-dan-masyarakat, diakses 10 September 2020, Jam, 14.25 wib
} 
terhadap akan adanya kesejahteraan (well being) dari generasi mendatang. Dengan demikian, maka prinsip dari pembangunan berkelanjutan dapat juga dihasilkan dengan selalu memperhatikan 3 (tiga) aksioma yang ada yaitu: (a) adanya perlakukan akan masa kini dan juga masa mendatang yang dapat menempatkan nilai yang positif dalam jangka waktu yang sangat panjang, (b) menyadari sepenuhnya bahwa dengan adanya aset dari lingkungan dapat memberikan suatu kontribusi terhadap adanya economic well being, dan juga (c) dapat mengetahui akan kendala atau hambatan dari akibat adanya implikasi yang dapat timbul pada aset suatu lingkungan. Seiring dengan hal tersebut bahwa pembangunan yang berkelanjutan juga sering dapat dijabarkan dengan adanya perbaikan dari kualitas akan hidup dan juga pertumbuhan dari ekonomi yang disesuaikan dengan daya serta dukung dari lingkungan (carrying capacity) ${ }^{25}$.

Tujuan dari pembangunan yang berkelanjutan adalah tanpa adanya kemiskinan, kelaparan, adanya kesejahteraan dan juga kesehatan terhadap kehidupan, adanya pendidikan yang berkualitas bagi anak dan perempuan, kesetaraan gender yaitu tidak adan diskriminasi anaupun tindakan kekerasan antara laki-laki dan juga perempuan semuanya mendapatkan pemerataan hak-haknya, air yang bersih dengan sanitasi yang layak, juga energi yang memang bersih dan terjangkau, pekerjaan yang layak dan juga mendorong pertumbuhan ekonomi, adanya industri, dan berkurangnya kesenjangan, kota dan komunikasi yang berkelanjutan dengan adanya kota yang layak dan ramah anak, adanya konsumsi dan juga produksi yang bertanggungjawab, adanya penanganan dari perubahan iklim, perlindungan akan ekosistem laut dan darat, adanya perdamaian dan keadilan, kemitraan dalam mencapai tujuan ${ }^{26}$

Indikator dalam perlindungan anak dan perempuan juga harus melihat dan memperhatikan kebutuhan-kebutuhan dari anak dan perempuan, namun yang paling utama adalah mengakhiri kekerasan anak dan perempuan, dimana semua pihak-pihak yang terkait ikut terlibat dan berperan serta dalam memberikan perlindungan yang memadai akan hak anak dan perempuan, dan mengutamakan akan kebutuhan hidup anak dan perempuan baik dari aspek yuridis dan non yuridis, terjamin dan terpenuhinya akan hak dari anak dan perempuan dalam segala aspek bidang dan harus ada koordinasi dan kerjasama dengan berbagai pihak serta dukungan dari sumber daya manusia juga sarana dan prasarana yang ada, termasuk perangkat dari peraturan serta fasilitas yang dapat menunjang dan mendukung perlindungan anak dan perempuan dalam pembangunan yang berkelanjutan

Perlunya peraturan perundang-undnagan yang memberikan sanksi yang tegas bagi pelaku kekerasan terhadap anak dan perempuan, khususnya anak harus selalu diutamakan akan perlindungannya sebagai generasa penerus di masa mendatang, kekerasan yang dimaksud sangat luas cakupannya, seperti kekerasan fisik, juga psikis, seksual, bahkan penelantaran ekonomi atau juga tindak pidana perdagangan orang dimana berbagai macam dilakukan untuk menjual, menculik anak sebagai adanya bentuk eksploitasi seksual dan ekonomi, atau juga stop pernikahan anak diusia yang sangat muda

Menumbuhkan kesadaran dari keluarga, juga masyarakat serta pihak lainnya dalam upaya memberikan perlindungan, dimana perlindungan mencakup tidak hanya dalam memberikan kasih sayang saja, tetapi terpenuhinya kebutuhan yang ada, pendidikan dan juga pengajaran perlu adanya sekolah bagi anak-anak yang tidak mampu,

\footnotetext{
25 Yenny Yorisca, (2020) Pembangunan Hukum Yang Berkelanjutan : Langkah Penjaminan Hukum Dalam Mencapai Pembangunna Nasional Yang Berkelanjutan, Jurnal Legislasi Indonesia, Vol. 17 (1), hal. 103-104

https://www.kompas.com/skola/read/2020/02/21/070000369/konsep-pembangunan-berkelanjutan--tujuan-danindikator?page=all, diakses 12 September 2020, Jam, 18.15 wib
} 
serta adanya perbaikan gizi yang baik untuk pertumbuhan bagi kelangsungan hidup anak, semuanya berhak juga untuk mendapatkan adanya pendidikan dan juga untuk duduk di setiap bangku pada sekolah serta menikmati kanak-kanaknya bukan harus bekerja dalam mencari nafkah bagi kehidupannya dan keluarganya.

Proses aatau revitalisasi dari perlindungan anak dan perempuan juga dalam mencapai pembangunan yang berkelanjutan tidak lepas dari peran stakeholder dalam berkaitan dengan hak kesehatan, dengan mengurangi adanya gizi yang buruk bagi anakanak dan perempuan, pemberian obat-obatan bagi anak yang sakit, dan jika ada terdampak maka perlunya pengobatan yang memadai dan ruang rawat bagi penyembuhan luka-lukanya, atau adanya rehabilitasi bagi anak dan perempuan. Dalam mencapai pembangunan yang berkelanjutan ini perlunya adanya perhatian dari semua aspek yang menyangkut bidang kehidupan dalam menunjang dan memberikan perlindungan anak dan perempuan.

\section{PENUTUP}

1. Revitalisasi perlindungan dari anak dan perempuan yang sesuai dengan arah pembangunan yang berkelanjutan harus berdasarkan pada 3 (tiga) dari aksioma yang ada yaitu:

(a) adanya perlakukan akan masa kini dan juga masa mendatang yang dapat menempatkan nilai yang positif dalam jangka waktu yang panjang,

(b) perlu menyadari sepenuhnya bahwa dengan adanya aset dari lingkungan dapat memberikan suatu kontribusi terhadap adanya economic well being, dan

(c) dapat mengetahui akan kendala atau hambatan dari akibat adanya implikasi yang dapat timbul pada aset suatu lingkungan.

2. Perlindungan anak dan perempuan dalam menuju pembangunan yang berkelanjutan tanpa adanya kemiskinan, kelaparan, adanya kesejahteraan dan kesehatan bagi kehidupan, adanya pendidikan yang berkualitas bagi anak dan perempuan, kesetaraan gender yaitu tidak adan diskriminasi anaupun tindakan kekerasan antara laki-laki dan juga perempuan semuanya mendapatkan pemerataan hak-haknya, air yang bersih dengan sanitasi yang layak, adanya suatu nergi yang bersih dan juga terjangkau, pekerjaan yang layak dan juga mendorong pertumbuhan ekonomi, adanya industri, dan berkurangnya kesenjangan, kota dan komunikasi yang berkelanjutan dengan adanya kota yang layak dan ramah anak, adanya konsumsi dan juga produksi yang bertanggungjawab, adanya penanganan dari perubahan iklim, perlindungan akan ekosistem laut dan darat, adanya perdamaian dan keadilan, dan kemitraan

\section{DAFTAR PUSTAKA}

\section{Buku}

Barakati Morais, 2015, Perspektof Konsep Hak Asasi Manusia Dalam Mewujudkan Pembangunan Lingkungan Hidup Yang Berkelanjutan, Lex Et Societatis, Vol. 3 (8)

Dardiri Hasyim, 2008, Perencanaan Pembangunan Berwawasan HAM Menuju Pembangunan Berpusat Pada HAM, UNISIA, Jurnal Ilmu-Ilmu Sosial, Vol. 31 (68)

Dewi Yusriani Sapta, 2011, Peran Perempuan Dalam Pembagunan Berkelanjutan Women In Sustainable Development, Jurnal Pendidikan Lingkungan dan Pembangunan Berkelanjutan, Vol. 12 (2)

Irmansyah Rizky Ariestandi, 2013, Hukum Hak Asasi Manusia dan Demokrasi, Graha Ilmu, Yogyakarta

Murtadha Muthahhar, 1995, Falsafah Akhlak, Pustaka Hidayah, Bandung 
Nan Rahminawati, 2001, Isu Kesetaraan Laki-Laki dan Perempuan (Bias Gender), MIMBAR Jurnal Sosial dan Pembangunan, Vol. 17 (3)

Probosiwi Ratih, 2015, Perempuan dan Perannya dalam Pembangunan Kesejahteraan Sosial, NATAPRAJA Jurnal Kajian Ilmu Administrasi Negara, Vol. 3 (1)

Rihardi Satrio Ageng, 2018, Perlundungan Hukum Terhadap Hak-Hak Anak Perempuan Sebagai Korban Eksploitasi Seksual, Jurnal Literasi Hukum Vol. 2 (1)

Rumtianing Irma, 2014, Kota Layak Anak Dalam Perspektif Perlindungan Anak, Jurnal Pendidikan Pancasila dan Kewarganegaraan, Vol 27 (1)

R. Subekti dan R. Tjitrosudibio, 2001, Kitab Undang-Undang Hukum Perdata, PT.Pradnya Paramita, Jakarta

Simbolon Laurensius Arliman, 2016, Partisipasi Masyarakat di Dalam Perlindungan Anak Yang Berkelanjutan Sebagai Bentuk Kesadaran Hukum, Padjajaran Journal of Law, Vol. 3 (2)

Yenny Yorisca, (2020) Pembangunan Hukum Yang Berkelanjutan : Langkah Penjaminan Hukum Dalam Mencapai Pembangunna Nasional Yang Berkelanjutan, Jurnal Legislasi Indonesia, Vol. 17 (1)

Zaitunah Subhan, 2004, Kekerasan Terhadap Perempuan. Pustaka Pesantren: Yogyakarta

Undang-Undang Dasar 1945

Undang-Undang Nomor 7 Tahun 1984 Tentang Pengesahan Konvensi Mengenai Penghapusan Segala Bentuk Diskriminasi Terhadap Wanita (Convention On The Elimination Of All Forms Of Discrimination Against Women).

Kitab Undang-Undang Hukum Perdata (KUHPER)

Undang-Undang Nomor 4 Tahun 1979 Tentang Kesejahteraan Anak

Undang-Undang Nomor 39 Tahun 1999 Tentang Hak Asasi Manusia

Undang-Undang Nomor 23 Tahun 2004 Tentang Penghapusan Kekerasan Dalam Rumah Tangga

Undang-Undang Nomor 11 Tahun 2012 Tentang Sistem Peradilan Pidana Anak

Undang-Undang Nomor 35 Tahun 2014 Tentang Perubahan Undang-Undang Nomor 23 Tahun 2002 Tentang Perlindungan Anak

https://puskapa.org/seri-belajar/722/diakses, 2 September 2020, Jam, 11.20 wib

https://www.komnasperempuan.go.id/read-news-siaran-pers-komnas-perempuancatatan-komnas-perempuan-33-tahun-ratifikasi-konvensi-cedaw-di-indonesia, diakses 4 September 2020, Jam, 09.00 wib

https://www.voaindonesia.com/a/ketidaksetaraan-gender-masih-tinggi-di-indonesia/5316082.html, diakses 7 September 2020, Jam, $19.30 \mathrm{wib}$

https://www.kemenpppa.go.id/index.php/page/read/31/1667/kesetaraan-genderperlu-sinergi-antar-kementerian-lembaga-pemerintah-daerah-dan-masyarakat, diakses 10 September 2020, Jam, 14.25 wib

https://www.kompas.com/skola/read/2020/02/21/070000369/konseppembangunan-berkelanjutan--tujuan-dan-indikator?page=all, diakses $\quad 12$ September 2020, Jam, 18.15 wib 